\title{
Impact of Working Capital on Financial Performance of Construction Material Support Companies in Oman
}

\author{
Dr. Nithya Ramachandran, Ms. Mary Pauline Santos and Ms. Indu Unnikrishnan \\ Lecturer, Department of Business Studies, \\ University of Technology and Applied Sciences (Ibra) \\ Sultanate of Oman.
}

DOI: $10.31364 / \mathrm{SCIRJ} / \mathrm{v} 8.18 .2020 . P 0820798$

http://dx.doi.org/10.31364/SCIRJ/v8.i8.2020.P0820798

\begin{abstract}
Working capital plays an important role in the profitability of companies. A high financial performance is expected if there is an efficient working capital management. The study was conducted to investigate the impact of working capital management on financial performance by using the data collected from seven listed firms in Muscat Securities Market under industrial sector-construction material support category. The study covered 7 years, from 2013 to 2018. The efficiency of the working capital was measured through the cash conversion cycle. A conceptual framework was needed to complete the study. The analysis of data has been segmented into three models with each area of profit kept as dependent variable. The parts are gross profit, net profit and operating profit kept as dependent variable and analysed using correlation, regression and annova. The three models showed a positive relationship between inventory conversion period, average collection period, average payment period and profitability.
\end{abstract}

Key Words: Working Capital, Financial Performance, Inventory Cycle, Average Collection, Average Collection Period, Average Payment Period.

\section{Introduction}

The importance of finance in a business can be rightly expressed as 'Finance is the life blood of a business'. A study on financial performance of a company can be done in different angles. Working capital management has more emphasis on profitability and financial performance of firm. Basically, financial analysis gives more emphasis on profitability rather than liquidity of the firm. Profitability being financial objective of any firm and ability to handle short-term obligations represented as liquidity. Effective utilization of resources to enhance productivity paves way for higher profitability. The total capital of a firm categorised into fixed capital which creates productive capacity and working capital which is utilization of the productive capacity. (Panigrahi, 2014).

A firm's efficiency to manage short-term financial obligations can be measured with working capital which is the difference between current assets and current liabilities. Thus, proper management of working capital leads to positive effect on profitability and liquidity position of a firm. The funds required for day - to - day operations of a business is termed as working capital. By maintaining adequate working capital the balance between liquidity and profitability can be maintained. The two major working capital policies of a firm are aggressive and conservative working capital. Aggressive policy is applied when short-term financing is more than planned and conservative policy is applied when a firm depends more on long-term funds for financing needs. (Luqman, 2014). Working capital management is a tool to analyse the performance of the organisation. When there is inequality in working capital, the profitability and frowth of a firm is affected. While managing the current assets of a firm there exists a conflict between profitability and liquidity. If a firm does not invest adequately in current assets there arises the risk of decrease in profitability. Sound working capital management techniques will help to achieve the trade-off between profitability and liquidity of a firm. (Luqman, 2014). 


\section{Historical background of the case study}

The infra structure development of the country had statrted its roots to the start of construction during the years 1975 onwards. The supporting companies also gained importance in the market to suppply material for the upcoming construction companies. There are 7 listed companies which support construction companies by supplying matreial to them.

- Al Anwar Ceramics Tile Company SAOG established in 1998 is the first manufacturer of ceramics tiles in the Sultanate of Oman.

- Oman Abrasives LLC established in 1986, manufactures a range of Grit from Mineral Slag which converts itself into Iron Silicate during the smelting and quenching process in the Copper Smelter.

- Al Maha Ceramics SAOG was set up in 2006 with a vision to provide quality ceramic tiles with world class design ingrained in every tile.

- Al Jazeera Tube Mills Company S.A.O.G. incorporated in 1997 was promoted by a group of Omani entrepreneurs with major share holdings and along with investments from the general public of the Sultanate of Oman, the company started producing Electric Resistance Welded (ERW) tubular products in circular square, and rectangular hollow sections, in both black and galvanized class.

- Construction Materials Industries SAOG was founded in -1977, the company has grown steadily ever since its inception. With a rage of pure Omani products which meet a wide range of needs, the company caters to several vital industries and projects, both locally and abroad through its three pioneering manufacturing plants.

- National Aluminium Products Company SAOG (NAPCO) was established in 1984 and is one of the leading extruders of aluminium profiles in the GCC market. Located in the Sultanate of Oman, the manufacturing plant is spread over 65,000 sq meters in the Rusayl Industrial estate.

- Oman Ceramics Company SAOG is an Oman-based company, which is engaged in the manufacture and sale of ceramic sanitary ware and other related products. The Company's ceramics products are exported to many countries, including the United States, the United Arad Emirates, Saudi Arabia, Bahrain, Qatar, Kuwait and South Africa and are available at over 1000 outlets around the world.

\section{Statement of the problem}

Mangement of working capital pays a vital role in gaining profitability of a business. The current economic crisis created a congestion on cash and credit which even has challenged the survival of business in the world. The current condition has led to the drastic reduction of production and sales has led to forceful reduction of expenses. In the current situation it is difficult for the companies to find external financing. Even if available, cost of borrowing is also expensive. The companies must plan for an effective liquidity management system.

The study aimed to find out the impact of working capital on financial performance of firms listed in MSM under industrial sector- construction material support category. There are seven companies listed in MSM as construction material support. The study is restricted to these seven companies for a period of eight years from 2011 to 2018. The financial data of the firms were collected from their annual reports. 


\section{Research Objectives}

The main objective of the paper is to examine the relationship between working capital management and profitability of construction material support companies listed in Muscat Securities Market (MSM).

\section{Research significance}

Infrastructure development plays a vital role in industrial development of a country. Construction sector is highly preferred in the economies which are moving forward towards industrial development. The companies that support construction sector with necessary materials support the development of the construction sector which ultimately develops infrastructure and results in economic development as well. In a country like Oman, which is marching towards infrastructure development, looking forward for industrial and tourism development, the construction companies and companies that support construction materials are of high priority. Thus, the study has selected all the seven companies listed in Muscat Securities Market (MSM) under industrial sector construction material support category. The companies selected are:

1. $\quad$ Al Anwar Ceramics Tile Company SAOG

2. Oman Abrasives LLC

3. Al Maha Ceramics SAOG

4. Al Jazeera Tube Mills Company S.A.O.G

5. Construction Materials Industries SAOG

6. National Aluminium Products Company SAOG

7. Oman Ceramics Company SAOG

\section{Review of Literature}

A dedication to the past research work related to working capital management is presented in this section. Many researchers have studied on working capital analysis using financial ratios.

Raghad Fawzi Sharaf and Fayez Salim Haddad in their study on The Relationship between Working Capital Management and Profitability for Industrial Companies Listed in Amman Stock Exchange (2015), has shown that the global financial crisis in 2008 impacted companies working capital by rising late payments on receivables and rising inventories, thereby reducing demand for their products and services. This triggered work capital shortages and needed liquidity. Consequently, organizational resource management, especially short-term working capital management, became a central part of the financial plans of companies around the world. The main objective of this study is to understand the relationship between the components of working capital management (receivables collection duration, inventory conversion time and payable deferment duration and cash conversion cycle) and profitability. The study sample includes all industrial public shareholding companies listed on the Amman Stock Exchange (ASE) during the period (2000-2012). All independent variables are shown as day units, while dependent and control variables are calculated as a ratio. The study found that a significant negative relationship between cash conversion cycle and profitability measures which means that shorter cash conversion cycle is more profitable. The findings showed that all control variables have statistically strong significant relationship with GOP, ROA and ROE. Size and sales growth have a positive relationship with profitability. This implies that large companies which have more funds to give credit to customers could create more sales, thus generate more profit. (Raghad Fawzi Sharaf, 2015)

Syed Ahsan Jamil, Mawih Kareem Al Ani, Faris Nasif Al Shubiri, studied on The Effect of Working Capital Management Efficiency on the Operating Performance of the Industrial Companies in Oman. Management decisions on working capital are one of financial management's short-term decisions such actions have included the short- assets and liabilities of a company. This 
focuses on the control of the company's total assets and current liabilities. WC management's main aim is to strike an ideal balance between WC management components. The aim of this study is to analyse the impact of management efficiency of working capital (WC) on the operating performance of industrial companies listed in the Sultanate of Oman's Muscat Securities Exchange (MSM). The thesis employed a non-experimental explanatory research method. Of the 48 industrial companies listed in the MSM, 37 were taken. The analysis used the data found in those companies 'annual reports for the period 2009-2013. The efficiency of WC management is measured by WC ratios such as cash conversion period, current ratio, current asset turnover, net WC ratio, while operating output is measured by net operating profit (NOP) and earnings before interest and tax. The study tested two models regarding the impact on profitability of WC management performance. The first model analysed the impact of WC efficiency on the NOP while the second model analysed the influence of WC efficiency on EBIT. The results of the regression showed that the first model is important and there is only a cash conversion period and NWCR has an effect on the NOP but the second model is negligible. The statistical analysis shows the same results in Model 2 and at the level of 37 manufacturing firms, but the regression analysis revealed that the model was negligible at 5\% and 1\%. R2 reflects 7.4 percent of the overall variance, meaning the model does not perceive any major shifts in EBIT. The overall statistical result of the study is that the industrial companies in Oman support their NOP but not the EBIT if they boost the efficiency of WC management in general and especially in the food sector. (Syed Ahsan Jamil, 2015)

Working capital management (WCM) which is the management of current assets and current liabilities has two main objectives, which are to increase firm's profitability and liquidity. Effective and efficient management of working capital is of paramount importance to firms due to its major significance on firm's profitability and liquidity. In a study conducted by Sumathi Kumaraswamy on the impact of working capital on the firm performance of cement manufacturing Gulf Cooperation Council (GCC) firms for the period 2008-2014, it showed that the profitability of the GCC cement manufacturing firms are greatly influenced by the average collection period and high inventory levels. Linear regression models were used to test four hypotheses pertaining to working capital components. The results of the regression model showed average collection period and inventory conversion period are the most significant factors followed by the average payment period. Furthermore, the study showed a positive relationship between inventory conversion period, average payment period with profitability and a negative relationship amid average collection period and firm profitability. It shows that the profitability of the GCC cement manufacturing firms are greatly influenced by the average collection period and high inventory levels. (Kumaraswamy,2016).

In a study conducted by Nai-Chiek, AIK1, Peck-Ling, Tee* entitled Working Capital management and financial performance of Malaysian construction sector companies for the period 2012-2016, he found out that shortening collection period and a positive working capital are significant to improve financial performance of local construction firms. Furthermore, an effective working capital has not much significant contribution to operating cash flow and share price of construction firms in Malaysia. In his study, he found out that proper management of accounts receivable is the most critical factor for the improvement of financial performance in local construction firms. (Nai-Chiek, 2019).

In a study conducted by Titus Mweta and Patrick Kipronoh entitled Effect of Working Capital Management on the Financial Performance: Evidence of Construction and Allied Sector Firms Listed at Nairobi Securities Exchange for the period 2012 to 2016, they found out that there is a weak insignificant association among inventory conversion, receivables collection period, payables payment period, cash conversion cycle, gross working capital, ratio of current assets to total assets, ratio of current liabilities to total liabilities, current ratio using return on assets and return on equity to measure financial performance. However with the use of gross profit margin to measure financial performance, the findings showed that there is a strong positive relationship among independent variables such as inventory conversion period, ratio of current assets to total assets, ratio of current liabilities to total liabilities and gross profit margin. (Titus Mweta, 2018). 
Working capital is essential in strengthening the liquidity position of firms. A weak liquidity position indicates a risk on the stability of the company. Nigeria was not an exception that was affected on the decline of the world oil prices. In the study conducted by Ajavi Micheal A. , Abogun Segun and Odediran Taiwo H., entitled Impact of working Capital Management on Financial Performance of Quoted Consumer Goods Manufacturing Firms in Nigeria, they found out that efficient working capital management increases financial performance. In their conclusion, there was a negative relationship between Cash Conversion Cycle (CCC) and financial performance while there was a positive relationship between Average Collection Period (ACP) and financial performance. As such, they recommended that firms within the industry may increase their average collection period above the present industry average collection period of 58 days and constant proper analysis of working capital components should be religiously observed to ensure that those critical areas for decision making process as it related to each of the performance measurement variables are identified and properly evaluated. (Ajayi Micheal A, 2017)

\section{Components of Working Capital}

Working capital management technique can be set by clear understanding about the components of the working capital. The four major components of working capital are:

1. Inventory conversion period (ICP)

2. Average collection period (ACP)

3. Average payment period (APP)

4. Cash conversion cycle (CCC)

\section{Inventory Conversion Period (ICP)}

Inventory is a major component of working capital. It consists of raw materials, work-in-progress and finished goods. To increase profitability, maintenance of optimal inventory levels are important. Inventory conversion period is the number of days between materials acquired and sold as product or service. This shows the efficiency of the firm as to how faster the firm is able to convert raw materials into finished goods. Shorter inventory conversion period shows that the firm is able to convert its investment in raw material into cash through sale of finished goods.

\section{Average Collection Period (ACP)}

The average number of days taken to receive the amount on credit sales made by the firm. The average number of days between date of credit sales and date in which amount on sales is collected from the customer. Credit standards are set to enable the management of credit and account receivables. Shorter collection period will enable the firm to receive amount on accounts receivable faster which may have a negative effect on increase in sale. Hence, the management must decide a moderate credit standard which will be beneficial both the firm and the customers.

\section{Average Payment Period (APP)}

The average number of days, the credit facility given by the supplier to the firm for purchase of raw material. Purchase of raw materials is often done on credit basis and the number of days given by the supplier for repayment of such purchases is represented as average payment period. A firm's refined accounts payable process would enhance the firm's future cash flow forecasts and thereby helps the firm to improve its liquidity, strengthen its working capital, mitigate potential funding gaps and realize higher profits. (Kumaraswamy, 2016)

\section{CCC}

The time between payment of raw materials and receipt of sale of finished goods is termed as Cash Conversion Cycle (CCC). (Megginson, 2010). The relationship between components of working capital and cash flow is known as CCC. The length of CCC 
depends on a firm's inventory conversion period, average collection period and average payment paeriod. In order to reduce the time between cash payments and receipts, firm's buy inventory on credit. In order to maximize shareholder value, the firm should manage the short term activities in a way that shortens the $\mathrm{CCC}$, which will enable the firm to operate with minimum cash investment. (Kumaraswamy, 2016).

\section{Conceptual Framework}

To fulfil the aim of the study i.e., to analyse the impact of working capital on financial performance on construction material support companies listed in Muscat Securities Market (MSM) a conceptual framework was needed. There have been a vast number of past studies made on working capital management and its relationship between profitability. The concept developed by Daniel Mogaka Makori and Ambrose Jagongo in the year 2013 has been adopted in the present study.

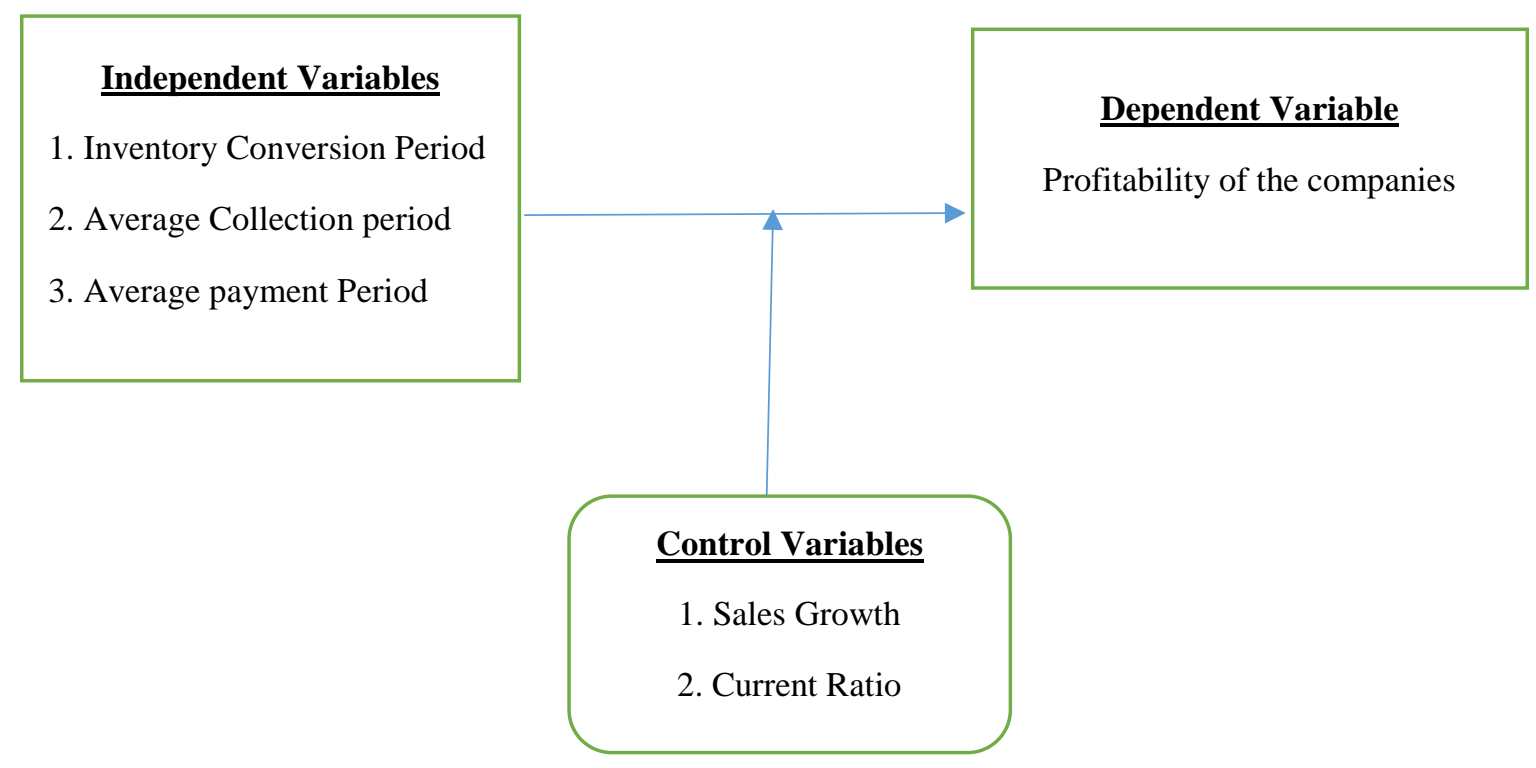

Source: (Daniel Mogaka Makori, 2013)

\section{Methodology, sources of data and sampling design}

The current study has taken all the 7 construction material support companies that are listed in MSM. The study used secondary data collected from annual reports of the company during the years 2013 - 2018. The data collected from annual reports were compiled as per the study objective requirements.

\section{Dependent and Independent Variables}

Dependent variable depends on other factors used in the study. Changes in the dependent variable may occur due to changes in independent variable. Independent variable is stable an unaffected by other variables used in the study.

The present study is to understand the relationship between Cash Conversion Cycle and profitability of selected companies. Hence, Return on Assets (ROA) will be the dependent variable and components of working capital i.e. inventory conversion 
period, average collection period, average payment period and cash conversion cycle are independent variables. The current ratio and sales growth are set as control variables.

\section{Hypothesis}

The first step of any research is to frame a testable hypothesis. Hypothesis is a tentative prediction about the nature of relationship between two or more variables. The relationship between components of working capital on profitability of a firm can be measured by testing the following formulated hypothesis:

H1: There is no significant relationship between Inventory Conversion Period and profitability. H2: There is no significant relationship between Average Collection Period and profitability. H3: There is no significant relationship between Average Payment Period and profitability.

\section{Research Model}

The effects of working capital management on the firm's profitability are modeled using the following regression equations to obtain the estimates:

$\mathrm{ROA}=\mathrm{f}(\mathrm{ACP}, \mathrm{ICP}, \mathrm{APP}, \mathrm{CCC}, \mathrm{GROWTH}, \mathrm{CR})$

Model 1: ROAit $=\beta_{0}+\beta_{1} \mathrm{ACP}_{\mathrm{it}}+\beta_{2} \mathrm{GROWTH}_{\mathrm{it}}+\beta_{3} \mathrm{CR}_{\mathrm{it}}+\varepsilon_{\mathrm{it}}$

Model 2: $\mathrm{ROA}_{\mathrm{it}}=\beta_{0}+\beta_{1} \mathrm{ICP}_{\mathrm{it}}+\beta_{2} \mathrm{GROWTH}_{\mathrm{it}}+\beta_{3} \mathrm{CR}_{\mathrm{it}}+\varepsilon_{\mathrm{it}}$

Model 3: $\mathrm{ROA}_{\mathrm{it}}=\beta_{0}+\beta_{1} \mathrm{APP}_{\mathrm{it}}+\beta_{2} \mathrm{GROWTH}_{\mathrm{it}}+\beta_{3} \mathrm{CR}_{\mathrm{it}}+\varepsilon_{\mathrm{it}}$

Model 4: $\mathrm{ROA}_{\mathrm{it}}=\beta_{0}+\beta_{1} \mathrm{CCC}_{\mathrm{it}}+\beta_{2} \mathrm{GROWTH}_{\mathrm{it}}+\beta_{3} \mathrm{CR}_{\mathrm{it}}+\varepsilon_{\mathrm{it}}$

Model 5: $\mathrm{ROA}_{\mathrm{it}}=\beta_{0}+\beta_{1} \mathrm{ACP}_{\mathrm{it}}+\beta 1 \mathrm{ICP}_{\mathrm{it}}+\beta_{1} \mathrm{APP}_{\mathrm{it}}+\beta_{2} \mathrm{GROWTH}_{\mathrm{it}}+\beta_{3} \mathrm{CR}_{\mathrm{it}}+\varepsilon_{\text {it }}$

Where,

ROA - Return on Assets

GROWTH - Sales growth

CR - Current Ratio

ACP - Average Collection Period

ICP - Inventory Conversion Period

APP - Average Payment Period

CCC - Cash Conversion Cycle.

$\mathrm{i}-$ Cross section dimensions ranging from 1 to 10

$\mathrm{t}$ - Time series dimensions ranging from 1 to 10

$\varepsilon-$ Error term

$\beta 0, \beta 1, \beta 2, \beta 3, \beta 4, \beta 5=$ Regression model coefficients

In the first regression model ACP has been regressed against the ROA, second regression model ICP has been regressed against the ROA, in third regression model APP has been regressed against the ROA. In fourth regression model CCC is regressed against the ROA. Finally, the three working capital measures have been regressed together against the ROA. (Daniel Mogaka Makori, 2013) 


\section{Empirical Analysis}

In this section, the empirical results are presented from quantitative data analysis using and E-Views and SPSS. Descriptive analysis is presented first followed by the Pearson's correlation and Regression analysis.

\begin{tabular}{|c|c|c|}
\hline \multicolumn{3}{|c|}{ Descriptive Statistics } \\
\hline Variable & Mean & Std. Deviation \\
\hline Gross profit ratio & 16.1041 & 19.11753 \\
\hline average collection period & 101.93 & 62.914 \\
\hline Stock turnover ratio & 3.1109 & 1.28831 \\
\hline Average payment period & 44.94 & 31.943 \\
\hline Current ratio & 2.3345 & 1.63701 \\
\hline Quick ratio & 1.7307 & 1.77235 \\
\hline Debt Equity ratio & 1.6472 & 6.70720 \\
\hline
\end{tabular}

The above table presents the summary statistics of the variables used in the present study for 7 firms in construction material support business. The mean value of gross profit is $16.10 \%$ with a standard deviation of $19.11 \%$. The average collection period is 101 days with standard deviation of 62 days. The firm takes 30 days to convert inventory into sales revenue with a standard deviation of 1 month. The table also shows that on an average the firm takes 44 days to pay its creditors with a standard deviation of 31 days. The current assets ratio being 2.335 and quick assets ratio at 1.73 . The debt equity ratio being $16 \%$ with a stand ard deviation of $6.7 \%$. 


\begin{tabular}{|c|c|c|c|c|c|c|c|c|c|c|}
\hline & \begin{tabular}{|c|} 
averag \\
$\mathrm{e}$ \\
collecti \\
on \\
period \\
\end{tabular} & $\begin{array}{c}\text { Stock } \\
\text { turnove } \\
\text { r ratio }\end{array}$ & $\begin{array}{c}\text { Averag } \\
\mathrm{e} \\
\text { payme } \\
\text { nt } \\
\text { period }\end{array}$ & $\begin{array}{c}\text { Curre } \\
\text { nt } \\
\text { ratio }\end{array}$ & $\begin{array}{l}\text { Gross } \\
\text { profit } \\
\text { ratio }\end{array}$ & $\begin{array}{l}\text { Net } \\
\text { profit } \\
\text { ratio }\end{array}$ & $\begin{array}{l}\text { Operati } \\
\text { ng } \\
\text { profit } \\
\text { ratio }\end{array}$ & $\begin{array}{l}\text { Quic } \\
\mathrm{k} \\
\text { ratio }\end{array}$ & $\begin{array}{c}\text { Debt } \\
\text { Equity } \\
\text { ratio }\end{array}$ \\
\hline \multirow{3}{*}{$\begin{array}{l}\text { average } \\
\text { collection } \\
\text { period }\end{array}$} & $\begin{array}{l}\text { Pearson } \\
\text { Correlatio } \\
\text { n }\end{array}$ & 1 & & & & & & & & \\
\hline & $\begin{array}{l}\text { Sig. (2- } \\
\text { tailed) }\end{array}$ & & & & & & & & & \\
\hline & $\mathrm{N}$ & 36 & & & & & & & & \\
\hline \multirow{3}{*}{$\begin{array}{l}\text { Stock } \\
\text { turnover } \\
\text { ratio }\end{array}$} & \begin{tabular}{|l} 
Pearson \\
Correlatio \\
n \\
\end{tabular} & .004 & 1 & & & & & & & \\
\hline & \begin{tabular}{|l}
$\begin{array}{l}\text { Sig. }(2- \\
\text { tailed) }\end{array}$ \\
\end{tabular} & .983 & & & & & & & & \\
\hline & $\mathrm{N}$ & 36 & 36 & & & & & & & \\
\hline \multirow{3}{*}{$\begin{array}{l}\text { Average } \\
\text { payment } \\
\text { period }\end{array}$} & \begin{tabular}{|l} 
Pearson \\
Correlatio \\
$\mathrm{n}$ \\
\end{tabular} & .310 & -.160 & 1 & & & & & & \\
\hline & $\begin{array}{l}\text { Sig. (2- } \\
\text { tailed) }\end{array}$ & .066 & .352 & & & & & & & \\
\hline & $\mathrm{N}$ & 36 & 36 & 36 & & & & & & \\
\hline \multirow{3}{*}{ Current ratio } & \begin{tabular}{|l} 
Pearson \\
Correlatio \\
$\mathrm{n}$ \\
\end{tabular} & .296 & -.090 & .111 & 1 & & & & & \\
\hline & $\begin{array}{l}\text { Sig. (2- } \\
\text { tailed) }\end{array}$ & .080 & .600 & .520 & & & & & & \\
\hline & $\mathrm{N}$ & 36 & 36 & 36 & 36 & & & & & \\
\hline \multirow{3}{*}{$\begin{array}{l}\text { Gross profit } \\
\text { ratio }\end{array}$} & \begin{tabular}{|l} 
Pearson \\
Correlatio \\
$\mathrm{n}$ \\
\end{tabular} & -.133 & .116 & $.527^{* *}$ & $.409^{*}$ & 1 & & & & \\
\hline & $\begin{array}{l}\text { Sig. (2- } \\
\text { tailed) }\end{array}$ & .438 & .501 & .001 & .013 & & & & & \\
\hline & $\mathrm{N}$ & 36 & 36 & 36 & 36 & 36 & & & & \\
\hline \multirow{3}{*}{$\begin{array}{l}\text { Net profit } \\
\text { ratio }\end{array}$} & \begin{tabular}{|l} 
Pearson \\
Correlatio \\
$\mathrm{n}$ \\
\end{tabular} & -.192 & .118 & $.539^{* *}$ & .229 & $.935^{* *}$ & 1 & & & \\
\hline & \begin{tabular}{|l} 
Sig. (2- \\
tailed)
\end{tabular} & .261 & .492 & .001 & .178 & .000 & & & & \\
\hline & $\mathrm{N}$ & 36 & 36 & 36 & 36 & 36 & 36 & & & \\
\hline $\begin{array}{l}\text { Operating } \\
\text { profit ratio }\end{array}$ & $\begin{array}{l}\text { Pearson } \\
\text { Correlatio } \\
n\end{array}$ & -.196 & .123 & $.565^{* *}$ & .179 & $.943^{* *}$ & $.992^{* * *}$ & 1 & & \\
\hline
\end{tabular}




\begin{tabular}{|c|c|c|c|c|c|c|c|c|c|c|}
\hline & $\begin{array}{l}\text { Sig. (2- } \\
\text { tailed) }\end{array}$ & .252 & .476 & .000 & .296 & .000 & .000 & & & \\
\hline & $\mathrm{N}$ & 36 & 36 & 36 & 36 & 36 & 36 & 36 & & \\
\hline \multirow{3}{*}{ Quick ratio } & $\begin{array}{l}\text { Pearson } \\
\text { Correlatio } \\
\mathrm{n}\end{array}$ & .215 & -.017 & .096 & $.921^{* *}$ & $.558^{* *}$ & .321 & .296 & 1 & \\
\hline & $\begin{array}{l}\text { Sig. (2- } \\
\text { tailed) }\end{array}$ & .209 & .922 & .576 & .000 & .000 & .057 & .080 & & \\
\hline & $\mathrm{N}$ & 36 & 36 & 36 & 36 & 36 & 36 & 36 & 36 & \\
\hline \multirow{3}{*}{$\begin{array}{l}\text { Debt Equity } \\
\text { ratio }\end{array}$} & $\begin{array}{l}\text { Pearson } \\
\text { Correlatio } \\
\mathrm{n}\end{array}$ & .180 & -.021 & .019 & .018 & -.202 & -.170 & -.175 & -.072 & 1 \\
\hline & $\begin{array}{l}\text { Sig. (2- } \\
\text { tailed) }\end{array}$ & .292 & .902 & .914 & .918 & .237 & .322 & .306 & .678 & \\
\hline & $\mathrm{N}$ & 36 & 36 & 36 & 36 & 36 & 36 & 36 & 36 & 36 \\
\hline
\end{tabular}

\section{Data Analysis}

The analysis of data has been segmented into three models with each area of profit kept as dependent variable. The parts are gross profit, net profit and operating profit kept as dependent variable and analysed using correlation, regression and annova.

\begin{tabular}{|c|c|c|c|c|c|c|}
\hline \multicolumn{7}{|c|}{ Correlation } \\
\hline \multirow{2}{*}{\multicolumn{2}{|c|}{ Model }} & \multicolumn{2}{|c|}{ Unstandardized Coefficients } & \multirow{2}{*}{$\begin{array}{c}\text { Standardized } \\
\text { Coefficients } \\
\text { Beta }\end{array}$} & \multirow[t]{2}{*}{$\mathrm{t}$} & \multirow[t]{2}{*}{ Sig. } \\
\hline & & $\mathrm{B}$ & Std. Error & & & \\
\hline \multirow{7}{*}{1} & (Constant) & -4.270 & 6.107 & & -.699 & .490 \\
\hline & average collection period & -.124 & .029 & -.408 & -4.282 & .000 \\
\hline & Stock turnover ratio & 2.947 & 1.298 & .199 & 2.270 & .031 \\
\hline & Average payment period & .382 & .054 & .639 & 7.081 & .000 \\
\hline & Current ratio & -4.584 & 2.721 & -.393 & -1.685 & .103 \\
\hline & Quick ratio & 10.191 & 2.462 & .945 & 4.139 & .000 \\
\hline & Debt Equity ratio & -.177 & .250 & -.062 & -.706 & .486 \\
\hline
\end{tabular}

\begin{tabular}{|l|c|c|c|c|c|}
\hline \multicolumn{7}{|c|}{ Regression } \\
\hline Model & $\mathrm{R}$ & R Square & $\begin{array}{c}\text { Adjusted R } \\
\text { Square }\end{array}$ & $\begin{array}{c}\text { Std. Error of the } \\
\text { Estimate }\end{array}$ & Durbin-Watson \\
\hline 1 & $.891^{\mathrm{a}}$ & .794 & .751 & 9.53797 & 1.698 \\
\hline
\end{tabular}




\begin{tabular}{|l|c|c|c|c|c|c|}
\hline \multicolumn{7}{|c|}{ ANNOVA $^{\mathrm{a}}$} \\
\hline \multirow{2}{*}{ Model } & Sum of Squares & df & Mean Square & F & Sig. \\
\hline \multirow{3}{*}{1} & Regression & 10153.587 & 6 & 1692.265 & 18.602 & $.000^{\mathrm{b}}$ \\
\cline { 2 - 7 } & Residual & 2638.215 & 29 & 90.973 & & \\
\cline { 2 - 7 } & Total & 12791.802 & 35 & & & \\
\hline a. Dependent Variable: Gross profit ratio \\
\hline
\end{tabular}

Model 1: There is no significant relationship between Inventory Conversion Period and profitability. The regression results shows a positive relation between profitability and inventory conversion period. Thus hypothesis $\mathrm{H} 1$ is rejected and concluded that inventory conversion period is statistically significant and there is a positive relationship between inventory conversion period and profitability.

\begin{tabular}{|c|c|c|c|c|c|c|}
\hline \multicolumn{7}{|c|}{ Correlation } \\
\hline \multicolumn{2}{|c|}{ Model } & \multicolumn{2}{|c|}{ Unstandardized Coefficients } & \multirow{2}{*}{$\begin{array}{c}\text { Standardized } \\
\text { Coefficients } \\
\text { Beta } \\
\end{array}$} & \multirow[t]{2}{*}{$\mathrm{t}$} & \multirow[t]{2}{*}{ Sig. } \\
\hline & & B & Std. Error & & & \\
\hline \multirow{7}{*}{1} & (Constant) & -3.732 & 4.608 & & -.810 & .425 \\
\hline & average collection period & -.078 & .022 & -.462 & -3.560 & .001 \\
\hline & Stock turnover ratio & 1.871 & .980 & .228 & 1.910 & .066 \\
\hline & Average payment period & .228 & .041 & .688 & 5.593 & .000 \\
\hline & Current ratio & -.584 & 2.053 & -.090 & -.284 & .778 \\
\hline & Quick ratio & 2.603 & 1.858 & .436 & 1.401 & .172 \\
\hline & Debt Equity ratio & -.097 & .189 & -.062 & -.516 & .610 \\
\hline
\end{tabular}

\begin{tabular}{|c|c|c|c|c|c|}
\hline \multicolumn{7}{|c|}{ Regression } \\
\hline Model & $\mathrm{R}$ & R Square & $\begin{array}{c}\text { Adjusted R } \\
\text { Square }\end{array}$ & $\begin{array}{c}\text { Std. Error of the } \\
\text { Estimate }\end{array}$ & Durbin-Watson \\
\hline 1 & $.785^{\mathrm{a}}$ & .617 & .537 & 7.19771 & 1.375 \\
\hline \multicolumn{6}{|c|}{ a. Predictors: (Constant), Debt Equity ratio, Current ratio, Stock turnover ratio, Average } \\
payment period, average collection period, Quick ratio \\
\hline
\end{tabular}




\begin{tabular}{|l|c|c|c|c|c|c|}
\hline \multicolumn{7}{|c|}{ ANNOVA $^{\mathrm{a}}$} \\
\hline \multirow{2}{*}{ Model } & Sum of Squares & df & Mean Square & F & Sig. \\
\hline \multirow{3}{*}{1} & Regression & 2415.537 & 6 & 402.590 & 7.771 & $.000^{\mathrm{b}}$ \\
\cline { 2 - 7 } & Residual & 1502.404 & 29 & 51.807 & & \\
\cline { 2 - 7 } & Total & 3917.941 & 35 & & & \\
\hline \multicolumn{7}{|l}{} \\
\hline
\end{tabular}

Model 2: There is no significant relationship between Average Collection Period and profitability. The regression results shows a positive relation between profitability and inventory conversion period. Thus hypothesis $\mathrm{H} 2$ is rejected and concluded that inventory conversion period is statistically significant and there is a positive relationship between average collection period and profitability.

\begin{tabular}{|c|c|c|c|c|c|c|}
\hline \multicolumn{7}{|c|}{ Correlation } \\
\hline \multirow{2}{*}{\multicolumn{2}{|c|}{ Model }} & \multicolumn{2}{|c|}{ Unstandardized Coefficients } & \multirow{2}{*}{$\begin{array}{c}\text { Standardized } \\
\text { Coefficients } \\
\text { Beta } \\
\end{array}$} & \multirow[t]{2}{*}{$\mathrm{t}$} & \multirow[t]{2}{*}{ Sig. } \\
\hline & & $\mathrm{B}$ & Std. Error & & & \\
\hline \multirow{7}{*}{1} & (Constant) & -2.727 & 4.770 & & -.572 & .572 \\
\hline & average collection period & -.082 & .023 & -.449 & -3.637 & .001 \\
\hline & Stock turnover ratio & 1.976 & 1.014 & .221 & 1.948 & .061 \\
\hline & Average payment period & .258 & .042 & .716 & 6.117 & .000 \\
\hline & Current ratio & -2.057 & 2.125 & -.293 & -.968 & .341 \\
\hline & Quick ratio & 3.850 & 1.923 & .593 & 2.002 & .055 \\
\hline & Debt Equity ratio & -.095 & .195 & -.055 & -.487 & .630 \\
\hline
\end{tabular}

\begin{tabular}{|l|c|c|c|c|c|}
\hline \multicolumn{7}{|l|}{ Model } & $\mathrm{R}$ & R Square & $\begin{array}{c}\text { Adjusted R } \\
\text { Square }\end{array}$ & $\begin{array}{c}\text { Std. Error of the } \\
\text { Estimate }\end{array}$ & Durbin-Watson \\
\hline 1 & $.808^{\mathrm{a}}$ & .653 & .581 & 7.45001 & 1.468 \\
\hline
\end{tabular}




\begin{tabular}{|l|c|c|c|c|c|c|}
\hline \multicolumn{7}{|c|}{ ANNOVA $^{\text {a }}$} \\
\hline \multirow{3}{*}{1} & Sum of Squares & df & Mean Square & F & Sig. \\
\cline { 2 - 7 } & Regression & 3026.347 & 6 & 504.391 & 9.088 & $.000^{\text {b }}$ \\
\cline { 2 - 7 } & Residual & 1609.578 & 29 & 55.503 & & \\
\hline & Total & 4635.926 & 35 & & & \\
\hline \multicolumn{7}{|l|}{$\begin{array}{l}\text { a. Dependent Variable: Operating profit ratio } \\
\text { payment period, average collection period, Quick ratio }\end{array}$} \\
\hline
\end{tabular}

Model 3: There is no significant relationship between Average Payment Period and profitability. The regression results shows a positive relation between profitability and inventory conversion period. Thus hypothesis $\mathrm{H} 3$ is rejected and concluded that average payment period is statistically significant and there is a positive relationship between average payment period and profitability and it is concluded that an increase in accounts payable by 1 day is also associated with profitability.

\section{Conclusion}

The construction material supply firms have invested a large amount of working capital so they expect to manage with significant impact on profitability. From the study it is clear that there is no negative correlation between profitability and inventory conversion period, average payment period and average collection period. It can be suggested that the management can increase the value by reducing the number of days of accounts receivable and payments. 


\section{References}

1. Daniel Mogaka Makori, A. J. (2013, December). Working Capital Management and Firm Profitability: Empirical Evidence from Manufacturing and Construction Firms Listed on Nairobi Securities exchange, Kenya. International Journal of Accounting and Taxation, 1(1).

2. Kumaraswamy, S. (2016). Impact of Working Capital on Financial Performance of Gulf Cooperation Council Firms. International Journal of Economics and Financial Issues, 6(3), 11360-1142.

3. Luqman, S. A. (2014). A Comparative Analysis on Working Capital Management of Brewery Companies in Nigeria. SSRN.

4. Megginson, W. S. (2010). Financial Management. Mason, Ohio: South Western: Cengage Learning.

5. Panigrahi, D. A. (2014, October). Understanding the Working Capital Financing Strategy (A Case Study of Lupin Limited). Journal of Management Research \& Analysis, 1(1). 